Electrical Machines and Drives 


\section{Other Macmillan titles in Electrical and Electronic Engineering}

W. A. Atherton, From Compass to Computer

B. R. Bannister and D. G. Whitehead, Fundamentals of Modern Digital Systems

G. B. Clayton, Data Converters

J. C. Cluley, Electronic Equipment Reliability, second edition

J. C. Cluley, Transducers for Microprocessor Systems

R. F. W. Coates, Modern Communication Systems, second edition

Donard de Cogan, Solid State Devices - A Quantum Physics Approach

C. W. Davidson, Transmission Lines for Communication, second edition

M. E. Goodge, Analog Electronics

M. E. Goodge, Semiconductor Device Technology

B. A. Gregory, An Introduction to Electrical Instrumentation and Measurement Systems, second edition

Paul A. Lynn, An Introduction to the Analysis and Processing of Signals, third edition

Paul A. Lynn, Electronic Signals and Systems

A. G. Martin and F. W. Stephenson, Linear Microelectronic Systems

J. E. Parton, S. J. T. Owen and M. S. Raven, Applied Electromagnetics, second edition

Douglas A. Ross, Optoelectronic Devices and Optical Imaging Techniques

Trevor J. Terrell, Introduction to Digital Filters, second edition

M. J. Usher, Sensors and Transducers

L. A. Warnes, Electronic Materials

B. W. Williams, Power Electronics - Devices, Drivers and Applications

G. Williams, An Introduction to Electrical Circuit Theory

Macmillan New Electronics Series

Series Editor: Paul A. Lynn

Rodney F. W. Coates, Underwater Acoustic Systems

Paul A. Lynn, Radar Systems

A. F. Murray and H. M. Reekie, Integrated Circuit Design

Dennis N. Pim, Television and Teletext

M. J. N. Sibley, Optical Communications

Martin S. Smith, Introduction to Antennas

P. M. Taylor, Robotic Control

Alan Waters, Active Filter Design 


\title{
Electrical Machines and Drives
}

\section{An Introduction to Principles and Characteristics}

\author{
J.D. Edwards \\ Senior Lecturer \\ School of Engineering and Applied Sciences \\ The University of Sussex
}

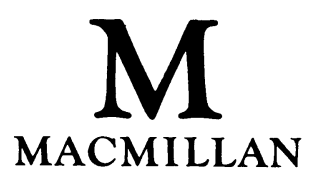


All rights reserved. No reproduction, copy or transmission of this publication may be made without written permission.

No paragraph of this publication may be reproduced, copied or transmitted save with written permission or in accordance with the provisions of the Copyright, Designs and Patents Act 1988, or under the terms of any licence permitting limited copying issued by the Copyright Licensing Agency, 33-4 Alfred Place, London WC1E 7DP.

Any person who does any unauthorised act in relation to this publication may be liable to criminal prosecution and civil claims for damages.

First edition 1991

Published by

MACMILLAN EDUCATION LTD

Houndmills, Basingstoke, Hampshire RG21 2XS

and London

Companies and representatives

throughout the world

Typeset by

TecSet Ltd, Sutton, Surrey

British Library Cataloguing in Publication Data

Edwards, J. D.

Electrical machines and drives: an introduction to principles and characteristics

1. Electric machinery

I. Title

621.46

ISBN 978-0-333-53651-3

ISBN 978-1-349-21313-9 (eBook)

DOI 10.1007/978-1-349-21313-9

Cover photograph courtesy of Printed Motors Limited. 


\section{Contents}

$\begin{array}{ll}\text { Preface } & \text { ix }\end{array}$

Notation, Units and Symbols $\quad x i$

1 General Principles 1

1.1 Introduction 1

1.2 Conductor moving in a magnetic field 2

$\begin{array}{lll}1.3 & \text { Electromagnetic induction } & 10\end{array}$

$\begin{array}{lll}1.4 & \text { Electromagnetic forces } & 15\end{array}$

$\begin{array}{lll}1.5 & \text { Magnetic materials } & 23\end{array}$

1.6 The magnetic circuit 29

$\begin{array}{lll}1.7 & \text { Permanent magnets } & 38\end{array}$

$\begin{array}{lr}\text { Problems } & 41\end{array}$

References $\quad 43$

2 Direct Current Machines $\quad 45$

2.1 Introduction 45

2.2 Fundamental principles 46

2.3 Energy conversion and losses $\quad 58$

$\begin{array}{lll}2.4 & \text { DC generators } & 61\end{array}$

$\begin{array}{lll}2.5 & \text { DC motors } & 64\end{array}$

$\begin{array}{lll}2.6 & \text { Special machines } & 72\end{array}$

$\begin{array}{ll}\text { Problems } & 74\end{array}$

$\begin{array}{ll}\text { References } & 75\end{array}$

3 Alternating Current Systems $\quad 77$

$\begin{array}{lll}3.1 & \text { Introduction } & 77\end{array}$

3.2 Generation of sinusoidal alternating voltages 77

$\begin{array}{lll}3.3 & \text { Polyphase systems } & 79\end{array}$

$\begin{array}{lll}3.4 & \text { Transformers } & 83\end{array}$

$\begin{array}{lr}\text { Problems } & 99\end{array}$

$\begin{array}{lr}\text { References } & 100\end{array}$ 
4 Introduction to AC Machines 102

$\begin{array}{lll}4.1 \text { Introduction } & 102\end{array}$

4.2 Distributed windings and the airgap magnetic field 103

$\begin{array}{ll}\text { 4.3 Combination of sinusoidally distributed fields } & 107\end{array}$

$\begin{array}{lll}4.4 & \text { Torque from sinusoidally distributed windings } & 110\end{array}$

$\begin{array}{lll}4.5 & \text { The rotating magnetic field } & 113\end{array}$

4.6 Voltage induced by a rotating magnetic field 116

$\begin{array}{lll}4.7 & \text { Multi-pole fields } & 121\end{array}$

$\begin{array}{ll}\text { 4.8 Introduction to practical windings } & 123\end{array}$

$\begin{array}{lr}\text { Problems } & 127\end{array}$

$\begin{array}{lr}\text { References } & 129\end{array}$

5 Synchronous Machines 130

$\begin{array}{lll}5.1 & \text { Introduction } & 130\end{array}$

5.2 Phasor diagram and equivalent circuit 132

$\begin{array}{lll}\text { 5.3 Synchronous machine characteristics } & 135\end{array}$

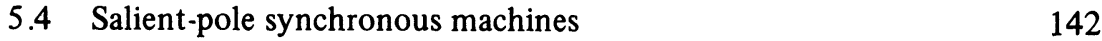

$\begin{array}{ll}\text { Problems } & 146\end{array}$

$\begin{array}{lr}\text { References } & 147\end{array}$

6 Induction Machines 148

$\begin{array}{lll}6.1 & \text { Introduction } & 148\end{array}$

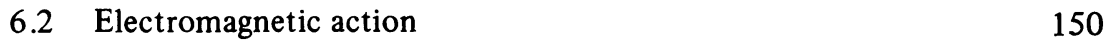

$\begin{array}{lll}6.3 & \text { Equivalent circuit } & 152\end{array}$

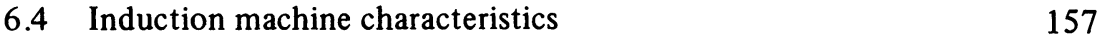

$\begin{array}{lll}6.5 & \text { Speed control of induction motors } & 164\end{array}$

$\begin{array}{lll}6.6 & \text { Single-phase induction motors } & 167\end{array}$

\begin{tabular}{ll}
6.7 & Linear induction motors \\
\hline
\end{tabular}

$\begin{array}{lr}\text { Problems } & 172\end{array}$

$\begin{array}{lr}\text { References } & 173\end{array}$

7 DC Drive Systems $\quad 174$

$\begin{array}{lll}7.1 \text { Introduction } & 174\end{array}$

$\begin{array}{lll}7.2 & \text { Power semiconductor devices } & 175\end{array}$

$\begin{array}{lll}7.3 & \text { AC/DC converters } & 177\end{array}$

$\begin{array}{lll}7.4 & \text { DC choppers } & 187\end{array}$

$\begin{array}{lll}7.5 & \text { DC drive system performance } & 188\end{array}$

$\begin{array}{lr}\text { Problems } & 192\end{array}$

$\begin{array}{lr}\text { References } & 192\end{array}$ 
8 AC Drive Systems 193

$\begin{array}{lll}8.1 \text { Introduction } & 193\end{array}$

$\begin{array}{ll}\text { 8.2 Three-phase bridge inverter } & 194\end{array}$

8.3 Synchronous and reluctance motor drives 201

8.4 Inverter-fed induction motor drives 204

$\begin{array}{ll}\text { 8.5 AC drive system performance } & 207\end{array}$

$\begin{array}{ll}\text { Problems } & 211\end{array}$

$\begin{array}{lr}\text { References } & 211\end{array}$

9 Stepper Motor Drives $\quad 213$

$\begin{array}{lll}9.1 \text { Introduction } & 213\end{array}$

$\begin{array}{ll}9.2 & \text { Variable-reluctance stepper motors } \\ 9.3 & 214\end{array}$

$\begin{array}{ll}9.3 \text { Hybrid stepper motors } & 216\end{array}$

$\begin{array}{lll}9.4 & \text { Electronic drive circuits } & 218\end{array}$

$\begin{array}{lll}9.5 & \text { Stepper motor characteristics } & 222\end{array}$

$\begin{array}{lll}9.6 & \text { Stepper motor control } & 224\end{array}$

$\begin{array}{ll}\text { Problems } & 226\end{array}$

References $\quad 226$

10 Brushless and Switched Reluctance Drives $\quad 227$

$\begin{array}{ll}10.1 \text { Introduction } & 227\end{array}$

10.2 Squarewave brushless DC drives 228

$\begin{array}{ll}\text { 10.3 Sinewave brushless DC drives } & 232\end{array}$

$\begin{array}{ll}10.4 \text { Switched reluctance drives } & 234\end{array}$

References 236

Appendix: Airgap Field Components and the Maxwell Stress 237

$\begin{array}{ll}\text { Bibliography } & 240\end{array}$

$\begin{array}{ll}\text { Answers to Problems } & 242\end{array}$

$\begin{array}{ll}\text { Index } & 244\end{array}$ 


\section{Preface}

This is an extensive revision of the second edition of Electrical Machines (Macmillan, 1986), incorporating the latest developments in electrical machines and drive systems. It retains the original aim of its predecessor: to give a short modern account of the principles of electrical machines and drives in a form accessible to the non-specialist, yet with sufficient rigour to provide a basis for more advanced studies. The first six chapters are unchanged in scope; they cover fundamental principles and the 'classical' electrical machines: DC commutator machines, AC synchronous machines and AC induction machines. The introduction to generalised machine theory has been removed, since it no longer seems appropriate in a text at this level. In its place are four new chapters on DC and AC drive systems.

Many applications of electrical machines require an adjustable speed. In the past this has been achieved with ingenious machines such as the AC commutator motors, or with constant-speed motors and mechanical variable-speed transmissions. These machines have been superseded by combinations of power electronic controllers and electrical machines which form the modern drive system. Chapters 7 and 8 cover the principles of power electronic controllers as applied to the classical AC and DC machines. Chapters 9 and 10 cover the newer nonclassical machines which work in conjunction with special-purpose electronic controllers: stepper motors, electronically commutated (or brushless) DC machines, and switched reluctance motors.

A distinctive feature of the earler book has been retained: a unified treatment of AC and DC machines based on the interaction of currents and magnetic fields, which gives a clear physical picture of the operating principles. The treatment is fully quantitative, and meets the requirements of rigour and simplicity by taking the simplest model of a machine which will demonstrate the essential features of its operation. Departures from the ideal are mentioned only briefly, since these form the subject of specialised study.

AC machines generally give students the most difficulty; a feature of this book is a novel approach to $\mathrm{AC}$ machines, introduced in chapter 4 and developed in chapters 5 and 6 . Traditionally, the concepts of MMF and flux dominate the theory; these are useful concepts, but they make the action of the machine difficult to visualise because they are one step removed from the fundamental current and field. I have therefore based the theory on the concepts of current density and flux density. These concepts give an immediate picture of the electromagnetic action; they also lead directly to the rotating field principle, the torque equation and the equivalent circuit. 
The reader is assumed to have an elementary knowledge of electromagnetism, circuit theory, and vectors. Background material is listed in the Bibliography at the end of the book. Space has limited the number of worked examples and problems for solution. In general the problems at the ends of the chapters are not straightforward, and they extend the material of the chapter. Readers who require more problems and worked examples will find them in the books listed in the Bibliography.

I wish to thank the Controller of Her Majesty's Stationery Office and the Longman Group for permission to reproduce figures 1.36 and 2.12 respectively, and several manufacturers, acknowledged in the text, for photographs of machines. I am grateful to reviewers and my university colleagues for suggestions; to second-year engineering students for encouraging me to find better ways of presenting machine theory; and to my wife for many hours of work with the computer in preparing both text and drawings.

J. D. Edwards 


\section{Notation, Units and Symbols}

SI units are used throughout the book, and the recommendations of the British Standards Institution [1] are followed for unit names and symbols. With electrical quantities, the usual convention is followed in denoting time-varying values by lower-case symbols and steady values or magnitudes by upper-case symbols. Three kinds of vector quantity occur in the book: space phasors, time phasors and three-dimensional vectors. Bold-face type is used for all these quantities, in line with normal practice, for example $\boldsymbol{I}, \boldsymbol{B}$. In some cases the same symbol may be used for a field vector or a space phasor; the context will always show which meaning is intended.

In general the recommendations of the Institution of Electrical Engineers [2] and the British Standards Institution [3] have been followed for symbols, abbreviations and subscripts. One exception is the symbol for linear current density; the recommended symbol $\boldsymbol{A}$ seems a poor choice because it is the established symbol for magnetic vector potential, and distinct symbols for both quantities are needed in advanced work. The symbol chosen is $K$, which follows Stratton [4] and some current practice.

There is one area of notation in which no uniformity exists: the choice of symbols for the infinitesimal elements in line, surface and volume integrals. After careful consideration the notation adopted is that of Stratton [4], in which $\mathrm{d} s, \mathrm{~d} a$ and $\mathrm{d} v$ denote the elements of path length, area and volume respectively. This is a consistent and convenient notation; it justifies the use of the subscript $\mathrm{s}$ for the tangential component of a vector; it releases capital letters for designating finite regions or quantities; and there is no confusion in advanced work between the symbols for length or area and the Poynting vector $\boldsymbol{S}$ or the vector potential $\boldsymbol{A}$.

The following lists refer only to the usage in this book. Further information will be found in the references already cited and in Massey [5]. 
List of principal symbols

\begin{tabular}{|c|c|c|c|}
\hline Symbol & Quantity & Unit & Unit symbol \\
\hline$A$ & area & square metre & $\mathrm{m}^{2}$ \\
\hline$a$ & radius & metre & $\mathrm{m}$ \\
\hline$B, B$ & magnetic flux density & tesla & $\mathrm{T}$ \\
\hline$B$ & flux density phasor & tesla & $\mathrm{T}$ \\
\hline$C$ & capacitance & farad & $\mathbf{F}$ \\
\hline $\mathrm{d} a, \mathrm{~d} a$ & element of area & square metre & $\mathrm{m}^{2}$ \\
\hline $\mathrm{d} s, \mathrm{~d} s$ & element of path length & metre & $\mathrm{m}$ \\
\hline $\mathrm{d} v$ & element of volume & cubic metre & $\mathrm{m}^{3}$ \\
\hline $\boldsymbol{E}, E$ & electric field strength & volt/metre & $\mathrm{V} / \mathrm{m}$ \\
\hline \multirow[t]{2}{*}{$\boldsymbol{E} ; E$} & excitation voltage phasor; & & \\
\hline & RMS magnitude & volt & V \\
\hline \multirow[t]{2}{*}{$\boldsymbol{E} ; E$} & induced EMF phasor; & & \\
\hline & RMS magnitude & volt & V \\
\hline$E, e$ & electromotive force & volt & V \\
\hline $\boldsymbol{F}, \boldsymbol{F}$ & mechanical force & newton & $\mathbf{N}$ \\
\hline$F$ & magnetomotive force & ampere & A \\
\hline$F_{x}$ & $x$ component of force & newton & $\mathbf{N}$ \\
\hline$f, f$ & force per unit volume & newton/metre ${ }^{3}$ & $\mathrm{~N} / \mathrm{m}^{3}$ \\
\hline$f$ & frequency & hertz & $\mathrm{Hz}$ \\
\hline$g$ & airgap length & metre & $\mathrm{m}$ \\
\hline $\boldsymbol{H}, \boldsymbol{H}$ & magnetising force & ampere/metre & $\mathrm{A} / \mathrm{m}$ \\
\hline$I ; I$ & current phasor; RMS magnitude & ampere & A \\
\hline$I_{0}$ & no-load current & ampere & $\mathbf{A}$ \\
\hline$I_{01}$ & loss component of $I_{0}$ & ampere & $\mathbf{A}$ \\
\hline
\end{tabular}




\begin{tabular}{|c|c|c|c|}
\hline$I_{0 \mathrm{~m}}$ & magnetising component of $I_{0}$ & ampere & $\mathbf{A}$ \\
\hline$I, i$ & current & ampere & $\mathbf{A}$ \\
\hline$J, J$ & current density & ampere/metre ${ }^{2}$ & $\mathrm{~A} / \mathrm{m}^{2}$ \\
\hline$J$ & moment of inertia & kilogram metre ${ }^{2}$ & $\mathrm{~kg} \mathrm{~m}^{2}$ \\
\hline$j$ & $\pi / 2$ operator, $\sqrt{ }(-1)$ & - & - \\
\hline$K, K$ & linear current density & ampere/metre & $\mathrm{A} / \mathrm{m}$ \\
\hline $\boldsymbol{K}$ & current density phasor & ampere/metre & $\mathrm{A} / \mathrm{m}$ \\
\hline$K$ & DC machine constant & $\left\{\begin{array}{l}\text { volt second/weber radian } \\
\text { newton metre/ampere }\end{array}\right.$ & $\begin{array}{l}\mathrm{Vs} / \mathrm{Wb} \mathrm{rad} \\
\mathrm{N} \mathrm{m} / \mathrm{A}^{2}\end{array}$ \\
\hline$K_{\mathrm{a}}$ & armature constant & $\begin{array}{l}\text { volt second/ampere radian } \\
\text { newton metre/weber ampere }\end{array}$ & $\begin{array}{l}\mathrm{V} \mathrm{s} / \mathrm{A} \mathrm{rad} \\
\mathrm{N} \mathrm{m} / \mathrm{Wb} \mathrm{A}\end{array}$ \\
\hline$K_{\mathrm{f}}$ & field constant & weber/ampere & $\mathrm{Wb} / \mathrm{A}$ \\
\hline$k$ & torque constant & newton metre/tesla ${ }^{2}$ & $\mathrm{~N} \mathrm{~m} / \mathrm{T}^{2}$ \\
\hline$L$ & self-inductance & henry & $\mathrm{H}$ \\
\hline$L_{\mathrm{m}}$ & magnetising inductance & henry & $\mathrm{H}$ \\
\hline$l$ & leakage inductance & henry & $\mathrm{H}$ \\
\hline$l$ & length & metre & $\mathrm{m}$ \\
\hline$M$ & mutual inductance & henry & $\mathrm{H}$ \\
\hline$m$ & number of phases & - & - \\
\hline$N$ & number of turns & - & - \\
\hline$n$ & Steinmetz index & - & - \\
\hline$n$ & turns ratio & - & - \\
\hline$P$ & power & watt & W \\
\hline$P_{\mathrm{e}}$ & electrical power & watt & W \\
\hline$P_{\mathrm{m}}$ & mechanical power & watt & W \\
\hline$p$ & $\mathrm{~d} / \mathrm{d} t$ operator & $1 /$ second & $1 / \mathrm{s}$ \\
\hline$p$ & number of pole pairs & - & - \\
\hline
\end{tabular}




\begin{tabular}{|c|c|c|c|}
\hline Symbol & Quantity & Unit & Unit symbol \\
\hline$p_{\mathrm{e}}$ & $\begin{array}{l}\text { eddy current power loss per } \\
\text { unit volume }\end{array}$ & watt $/$ metre ${ }^{3}$ & $\mathrm{~W} / \mathrm{m}^{3}$ \\
\hline$p_{\mathrm{h}}$ & $\begin{array}{l}\text { hysteresis power loss per } \\
\text { unit volume }\end{array}$ & watt $/$ metre $^{3}$ & $\mathrm{~W} / \mathrm{m}^{3}$ \\
\hline$q$ & electric charge & coulomb & $\mathrm{C}$ \\
\hline$R$ & resistance & ohm & $\Omega$ \\
\hline$R_{\mathrm{e}}$ & equivalent total resistance & ohm & $\Omega$ \\
\hline$R_{\mathrm{c}}$ & core loss resistance & ohm & $\Omega$ \\
\hline$r$ & radius & metre & $\mathrm{m}$ \\
\hline$S$ & reluctance & ampere/weber & $\mathrm{A} / \mathrm{Wb}$ \\
\hline$s$ & fractional slip & - & - \\
\hline$T$ & torque & newton metre & $\mathrm{N}$ m \\
\hline$T_{\mathrm{m}}$ & mechanical output torque & newton metre & $\mathrm{N}$ m \\
\hline$T_{\theta}$ & torque associated with angle $\theta$ & newton metre & $\mathrm{N}$ m \\
\hline$t, t$ & stress & newton/metre ${ }^{2}$ & $\mathrm{~N} / \mathrm{m}^{2}$ \\
\hline$t$ & time & second & s \\
\hline$U$ & magnetic potential difference & ampere & $\mathbf{A}$ \\
\hline$u, u$ & linear velocity & metre/second & $\mathrm{m} / \mathrm{s}$ \\
\hline $\boldsymbol{V} ; \boldsymbol{V}$ & voltage phasor; RMS magnitude & volt & V \\
\hline$V, v$ & terminal voltage, electric & & \\
\hline & potential difference & volt & V \\
\hline$w$ & energy, work done & joule & $\mathbf{J}$ \\
\hline$w_{\mathrm{e}}$ & electrical energy & joule & $\mathbf{J}$ \\
\hline$w_{\mathrm{h}}$ & $\begin{array}{l}\text { hysteresis energy loss per } \\
\text { unit volume }\end{array}$ & joule/metre ${ }^{3}$ & $\mathrm{~J} / \mathrm{m}^{3}$ \\
\hline
\end{tabular}




\begin{tabular}{|c|c|c|c|}
\hline$W_{\mathrm{m}}$ & magnetic stored energy & joule & $\mathbf{J}$ \\
\hline$X$ & reactance & ohm & $\Omega$ \\
\hline$X_{\mathbf{e}}$ & equivalent total reactance & ohm & $\Omega$ \\
\hline$X_{\mathrm{m}}$ & mutual or magnetising reactance & ohm & $\Omega$ \\
\hline$X_{\mathrm{s}}$ & synchronous reactance & ohm & $\Omega$ \\
\hline$x$ & leakage reactance & ohm & $\Omega$ \\
\hline$Z, Z$ & impedance & ohm & $\Omega$ \\
\hline$Z$ & maximum linear conductor density & $1 /$ metre & $1 / \mathrm{m}$ \\
\hline$\alpha, \beta, \gamma$ & general angles & radian & $\mathrm{rad}$ \\
\hline \multirow[t]{2}{*}{$\delta$} & load angle, angle between & & \\
\hline & magnetic field axes & radian & rad \\
\hline$\delta$ & depth of penetration & metre & $\mathrm{m}$ \\
\hline$\epsilon$ & voltage regulation & - & - \\
\hline$\eta$ & efficiency & - & - \\
\hline$\theta$ & angular displacement, rotor angle & radian & $\mathrm{rad}$ \\
\hline$\Lambda$ & permeance & weber/ampere & $\mathrm{Wb} / \mathrm{A}$ \\
\hline$\lambda_{h}$ & Steinmetz coefficient & - & - \\
\hline$\mu$ & absolute permeability $=\mu_{0} \mu_{r}$ & henry/metre & $\mathrm{H} / \mathrm{m}$ \\
\hline$\mu_{0}$ & magnetic constant $=4 \pi \times 10^{-7}$ & henry/metre & $\mathrm{H} / \mathrm{m}$ \\
\hline$\mu_{\mathrm{r}}$ & relative permeability & - & - \\
\hline$\rho$ & charge per unit volume & coulomb/metre ${ }^{3}$ & $\mathrm{C} / \mathrm{m}^{3}$ \\
\hline$\rho$ & resistivity $=1 / \sigma$ & ohm metre & $\Omega \mathrm{m}$ \\
\hline$\sigma$ & conductivity $=1 / \rho$ & siemens/metre & $\mathrm{S} / \mathrm{m}$ \\
\hline$\tau$ & time constant & second & s \\
\hline$\tau_{\mathrm{em}}$ & electromechanical time constant & second & s \\
\hline
\end{tabular}




\begin{tabular}{llll}
\hline Symbol & \multicolumn{1}{c}{ Quantity } & \multicolumn{1}{c}{ Unit } & Unit symbol \\
\hline$\Phi$ & magnetic flux phasor & weber & $\mathrm{Wb}$ \\
$\Phi$ & magnetic flux, flux per pole & weber & $\mathrm{Wb}$ \\
$\Phi_{1}$ & leakage flux & weber & $\mathrm{Wb}$ \\
$\phi$ & phase angle, angular displacement & radian & $\mathrm{rad}$ \\
$\psi$ & angular displacement & radian & $\mathrm{rad}$ \\
$\Omega, \omega$ & angular velocity & radian/second & $\mathrm{rad} / \mathrm{s}$ \\
$\omega$ & angular frequency $=2 \pi f$ & radian/second & $\mathrm{rad} / \mathrm{s}$ \\
$\omega_{\mathrm{r}}$ & rotor angular velocity & radian/second & $\mathrm{rad} / \mathrm{s}$ \\
$\omega_{\mathrm{s}}$ & synchronous angular velocity & radian/second & $\mathrm{rad} / \mathrm{s}$ \\
& & & \\
\hline
\end{tabular}

\section{General subscripts}

$\begin{array}{ll}\text { a } & \text { armature } \\ \text { av } & \text { average } \\ \text { f } & \text { field } \\ \text { m, max } & \text { maximum value } \\ \text { n } & \text { normal component } \\ \text { r } & \text { radial component } \\ \text { s } & \text { tangential component } \\ 1,2 & \text { primary, secondary; stator, rotor } \\ \alpha, \beta & \text { two-phase quantities } \\ \text { a, b,c } & \text { three-phase quantities }\end{array}$


Decimal prefixes

$\begin{array}{lll}10^{6} & \text { mega } & \mathrm{M} \\ 10^{3} & \text { kilo } & \mathrm{k} \\ 10^{-2} & \text { centi } & \mathrm{c} \\ 10^{-3} & \text { milli } & \mathrm{m} \\ 10^{-6} & \text { micro } & \mu\end{array}$

Abbreviations

$\begin{array}{ll}\text { AC } & \text { alternating current } \\ \text { DC } & \text { direct current } \\ \text { EMF } & \text { electromotive force } \\ \text { MMF } & \text { magnetomotive force } \\ \mathrm{rev} / \mathrm{min} & \text { revolutions per minute } \\ \mathrm{rev} / \mathrm{s} & \text { revolutions per second } \\ \mathrm{RMS} & \text { root-mean-square }\end{array}$




\section{References}

1 BS 3763, The International System of Units (SI) (London: British Standards Institution, 1976).

2 IEE, Symbols and Abbreviations for Electrical and Electronic Engineering, 3rd ed. (London: Institution of Electrical Engineers, 1980).

3 BS 5775, Specification for Quantities, Units and Symbols (London: British Standards Institution, 1982).

4 J. A. Stratton, Electromagnetic Theory (New York: McGraw-Hill, 1941).

5 B. S. Massey, Units, Dimensional Analysis and Physical Similarity (London: Van Nostrand Reinhold, 1971). 